\title{
LANGUAGE REPRESENTATION OF THE TIME CONCEPT IN ENGLISH ORAL NARRATIVE DISCOURSE
}

\author{
Natalia BIGUNOVA \\ Odesa I.I. Mechnikov National University, Ukraine \\ E-mail: natalbig@ukr.net \\ Sophiia DOMBROVSKA \\ National University "Odessa maritime academy", Ukraine \\ E-mail:sloika.lolo@gmail.com
}

\begin{abstract}
This study addresses two interrelated issues: first, the status of narratology, and second, the role of language means in manifestation of the time concept in oral narrative discourse. The article focuses on the semantic, morphological and syntactic means realizing the time concept in English oral narrative discourse. The authors offer their own classification of temporal meanings characteristic of oral narrative discourse. The classification includes the following temporal meanings: succession, priority, simultaneity, frequency / oneness, duration and time localization. The proportion of the defined temporal meanings in the investigated narrative discourses has been quantified as well, proving that the biggest layer of temporally coloured language items is formed by the temporal meaning of succession, while the rest of the meanings form approximately equal layers. The main part of the study presents and analyses language manifestation of each of the singled out temporal meanings in the oral narrative discourse. The study has also revealed a number of language units that can express a few temporal connotations and thus are included into the language bulks representing different temporal meanings. The authors come to affirming the complex nature of a linguistic signal and provide a detailed description how exactly a temporal meaning is signalled at each language level in oral narrative discourse.
\end{abstract}

KEYWORDS: concept, narrative, discourse, time, temporality, temporal meaning.

\section{Introduction}

The study of personal identity, gender stereotypes, and even "the world" has been successfully subjected to a cognitive orientation that views the human mind as the central and universal organizer of information, or the place where information about self and the world is centrally organized (Carreiras, 2010, David et. al., 2004, Evans and Green, 2006, Fauconnier, 2004, Wierzbicka, 2006, etc.). As Malouf writes: "It is all very well to regard language as simply "a means of communication". It may be that for poor handlers of a language and for those to whom it is new and unfamiliar, who use it only for the most basic exchanges. But for most of us it is also a machine for thinking, for feeling; and what can be thought and felt in one language - the sensibility it embodies, the range of phenomena it can take in, the activities of mind as well as the objects and sensations it can deal with - is different, both in quality and kind, from one language to the next" (Malouf, 2003, p. 44). In the field of cognitive linguistics, scholars, such as Lakoff (1982), Johnson (2014), Langacker and Ronald (1987), Talmy (2000), Herman (2011), have explored ways in which the structure of language is grounded in embodied human experience. One of the problems that cognitive linguistics is trying to overcome is the identification of language means that express certain meaning in discourse as the exchange of referentially denoted information, the way it is represented in the individual mind, encoded by semiotic means, and subsequently encoded by the interlocutor. Conceptualizing pieces of reality has become the centre of attention for such linguists as Arutyunova (1988), Bowerman and Levinson (1998), Bulygina and Shmelev (1997), Dem yankov (2005), Frumkina (1991), Kolegaeva (2018), Kubryakova (2005), Medin and Smith (1984), Stepanov (1991), Trask (1999), and others. The concept as a linguistic term helps to distinguish and study mental objects that represent units which express our conception of the world and create a schematic image of the word, making the model of consciousness accessible to perception. Lacoff operates with such concepts as cognitive models and mental spaces structured by them, which are a certain field of conceptualization of ideas. Within its framework situations are recognized: the past, the present and the future, as well as the construction of hypothetical situations and the interpretation of abstract categories. Mental spaces have a purely cognitive status and are absent beyond thought (Lakoff, 1982). Another linguistic area that has become the focus of the present study is narratology. Contemporary cognitive linguists hold the view that cognitive processes can be lodged not just in storytellers' reports about their own or others' utterances, and experiences, but also in modes of narration (individual or shared, retrospective, embedded, etc.), types of perspective (internal or external to the storyworld, stationary or dynamic, fine- or coarse-grained, etc.), and language patterns for 
situating narrated situations and events in space and time. Narrative discourse has been chosen an object for this research, as all the linguists who take interest in it (Genette, 1980, Gil', 2000, Labov, 1972, Longacre, 1974, Robinson, 1981, Ryan, 1991, Schiffrin, 1981, etc.) accentuate temporality as one of its invariant characteristics.

\section{Methodology}

The subject matter of the study is English-language oral narrative discourse and the scope of the study is language manifestation of temporal meanings in English-language oral narrative discourse.

The major aim of this study is to define the role of semantic, morphological and syntactic means in the realization of the time concept in oral narrative discourse. There is also a need to devise a classification of temporal meanings comprising oral narrative structure. The material under analysis is represented by oral narrative discourses on routine topics that last altogether 90 minutes, offered for listening purposes in the textbook "What a story!" (Underwood, Oxford University Press, 2002). Since the textbook does not offer a tapescript, we have worded all the narratives for the analysis. All the analyzed narrative discourses are personal stories that tell about some peculiar events, experienced by the speakers. The linguistic analysis of the selected data has been based on the application of general scientific methods, namely: the methods of synthesis and analysis that promoted the holistic research into narrative discourse; the method of observation that enabled the identification of the peculiar characteristics of the investigated data; the descriptive method that was helpful in establishing the variant and invariant characteristics of the data; special linguistic methods, namely: the contextualinterpretational method was used to find out the events' order and their significance for the narrator, to identify the narrators' and the interlocutors' roles; the cognitive discourse analysis was used to describe temporal characteristics of narrative discourses.

\section{Narrative discourse: definition and temporal function}

Despite the voluminous history of the research of narrative discourse, it is still an ambiguous notion. During the last decades the study of narrative moved away from what focused primarily on literary texts - such as Genette's Narrative Discourse and Bal's Narratology, and moved towards oral narratives in real-life communication.

For Genette (1980) the word narrative has three distinct meanings. It refers to:

"the narrative statement, the oral or written discourse that undertakes to tell of an event or a series of events;

the succession of events, real of fictitious that are the subjects of this discourse, and their several relations of linking, oppositions, repetition, etc.;

- the event that consists of someone recounting something: the act of narrating taken in itself" (Genette, 1980, pp. 25-26).

Bamberg views narratives as primary territories where co-conversationalists seek and find ways to mitigate the interactive trouble and fashion a portrayal of themselves in ways that are interactively useful. He also points out that participants in interactions constantly adjust their actions to what is created 'in the moment'. As Bamberg (2008) notes, actual talk-in-interaction as well as narratives-ininteraction become applications and deviations, all the way up to 'distortions' of what the 'actual' mind is able to accomplish. Therefore, the empirical domain to conduct this type of research can no longer be a description of the everyday, of talk, and of narratives-in-interaction, the way they are negotiated in daily routines. According to Longacre (1974), the narrative covers the telling of $a$ story and is distinguished from other discourse genres in the following ways: narrative discourse is usually in the first or third person, narrative discourse is actor-oriented, narrative discourse encodes accomplished time, and chronological linkage is necessary; narrative is also distinct from other genres because of plot. We suggest the following definition of narrative discourse: a kind of everyday communication, eventdriven, comprising actions arranged in a certain time and place, presented in chronological or other order, designated, but tailored to a particular addressee and the communicative purposes the narrator pursues. Recent theoretical developments have revealed that the narrative not only represents but also enacts or exemplifies how cognitive processes are anchored in collaborative discourse processes - how the mind is grounded in the participants' relations with one another and with their surrounding social and material environment (Herman, 2011, Jahn, 2005, Polanyi, 2008). Narratology has been working towards distinguishing a comprehensive storytelling structure and functions of narrative events (Labov, 1972, Polanyi, 2008, Robinson, 1981). Longacre insists that the audience expects the narrator to tell 
something which is interesting and has a reason to be told. It should also be able to make judgements and evaluate what is being reported. If the narrative is complete, the audience is able to sense its completion (Longacre, 1974). Robinson (1981) makes the point that routine or familiar activities, such as going shopping, watching television, or making a telephone call, would not be reportable as narratives unless there were some untoward element in the activity, for example, having one's wallet stolen in the department store. Events must be "remarkable" in order to succeed as personal narratives.

The componential structure of the oral narrative discourse, offered by Labov as long ago as in 1972, still remains the most convincing. Labov states that the oral narrative normally has a six-part structure, known as diamond-shaped model which includes: 1) abstract, 2) orientation, 3) complicating action, 4) evaluation, 5) result or resolution, 6) coda. Before recounting the story proper narrators generally provide short (usually one or two sentence) summary of the story, which he calls abstract. Then they identify in some way the time, place, persons, and their activity or situation (orientation). After that the speaker tells the events themselves - this is the main part, it is called complicating action and result. Recounting the story, speakers often evaluate them (evaluation). And finally the listener is returned to the time of speech with a phrase like "And that was that" or "And I don't know what happened to him afterwards" (coda) (Labov, 1972). It has been long reported that narrative discourses have distinctive language features. Biber (1992) associates the following features with the 'narrative style': verbs in the past tense and perfect aspect, third person pronouns, verbs of communication (such as tell, speak, report, admit), present participial clauses, synthetic negation, infrequent occurrence of present tense verbs and attributive adjectives, deictic forms to narratives ('there', 'then', 'they', etc.). Most researchers associate narratives with first person pronouns, activity verbs, the progressive aspect, as well as adverbial modifiers with a temporal meaning (for example, 'since', 'while') as typical markers of narration (Jahn, 2005, Herman, 2011, Labov, 1972, Schiffrin, 1981). Most of these features refer to time and have to be accounted for. It is with the feeling of this need that these brief studies have been prepared.

\section{Language explication of the concept of time in oral narrative discourse}

Narratologists insist that there is a temporal order in narrative texts (Schiffrin, 1981, Wolfson, 1982, Polanyi, 2008). The temporal function of the narrative discourse is seen as its ability to express time, to highlight certain moments, to provide the connection between them, to determine the significance of temporal succession, to provide the reasons for the result, to determine the meaning of time. The time of the story can be reported in various ways, according to the intentions of the narrator. It is the narrator's choice to emphasize particular events, expand them or background according to their significance to the story. Callaway and Lester (2002) claim that in every narrative, there are a number of underlying "facts" that constitute the demonstrable states and activities that occur in the story and the objects and properties involved in those states and activities. Additionally, there are a number of decisions made by the author as to which facts should be mentioned first (or even whether they should be mentioned at all, as in a mystery) and what style considerations should be involved in realizing the actual text. In every narrative an author also makes choices about which elements should be mentioned first, which second, and so on. What is meant here is not that one event occurred temporally before or after another event (logical ordering), or that the story occurred in the past relative to the narrator (chronological ordering), but rather the presentational ordering: that a specific event or state was mentioned by the author before or after the author decided to mention another particular state or event. They term this strict linear sequence the narrative stream, which represents the presentational ordering of the facts (Callaway and Lester, 2002, pp. 215-216). Genette calls the discordance between the narrative sequence and the temporal order anachrony. He says that "pinpointing and measuring the narrative's anachronies implicitly assumes the existence of a kind of zero degree that would be a condition of perfect temporal correspondence between story and narrative" (Genette, 1980, pp. 36).

The temporal function of narrative discourse becomes realized in markers of particular points in a narrative chain of events, the correlation among them, the anticipated ending, partially presupposed by the beginning of the story. Thus, the narrative is based on events, evolving in time. An event is made of different actions, each expressed by a verb used in a certain grammar tense. The temporal organization of narrative events determines the choice of language means. Temporality is expressed by: 1) subordinate conjunctions; 2) adverbs of time; 3 ) verbs of physical action; 4) nouns that have temporal meaning with / without a preposition; 5) adjectives that have temporal meaning (Bulygina and Shmelev, 
1997, Stepanov, 1991, Wierzbicka, 2006). The morphological tenses determine time with reference to the time point of the act of speech. Both the subject and the object of the verb can have temporal meaning in their semantics and can be specified attributively. Strictly speaking, solely adverbial characteristic can specify the temporal aspect of the verb (namely, an adverbial of time), however, the temporal colouring of the whole utterance is caused by the interaction of various components of the time cluster. Time becomes explicit in the lexical semantics of certain words. Words, word units and clauses are bearers of temporal seme. In the investigated data a number of words (verbs, nouns, adjectives, numerals, adverbs) that have temporal meaning in their semantic structure have been registered. "Lexical time" is seen as words that are defined as having temporal seme in their structure. These words can be differentiated from the point of view of the quantity of temporal component into those that directly mean time (time, today, yesterday, hour, year, then, last, etc.), and the words, in the lexical semantics of which temporal meaning is expressed syncretically, together with other semes (to wait, to plan, to be late, to hurry, quick, ancient, old-fashioned, etc.). The words that have temporal seme in the structure of their lexical meaning, include ordinal numerals first, second, third, etc., adjectives last, previous, next, further, necessary, nouns time, event, memory, experience. Future segment is represented by the verbs want, wish, plan, decide, adjectives "next, further, necessary", nouns "intention, plan". Past segment is represented by the verbs remember, forget, recollect, originate, nouns memory, experience, adjectives last, previous, old, ancient. Present segment is represented by the adverbs now, today. The significant lexical means that embody temporality in narrative discourse are the verbs of action semantics, as well as static-dynamic semantics, i.e. verbs of physical action, verbs of movement, change-of-state verbs, verbs of speech and cognition. At the syntactic level temporality is manifested by adverbial groups of time and manner, patterns with homogeneous predicates (expressed by verbs of physical action), chain succession of compound and complex sentences.

5. The classification of temporal meanings characteristic of oral narrative discourse

We suggest that the semantics of temporality is represented by the following temporal meanings: succession, priority, simultaneity, frequency / oneness, duration and time localization.

The quantitative presentation of the defined temporal meanings in the investigated data has proved to be different (see Table 1).

Table 1

The proportion of temporal meanings in narrative discourse

\begin{tabular}{|c|c|c|c|c|c|c|}
\hline $\begin{array}{c}\text { Temporal } \\
\text { meaning }\end{array}$ & succession & priority & simultaneity & $\begin{array}{c}\text { frequency } \\
\text { / oneness }\end{array}$ & duration & $\begin{array}{c}\text { time } \\
\text { localization }\end{array}$ \\
\hline $\begin{array}{c}\text { Usage rate, } \\
\%\end{array}$ & 58.2 & 6.7 & 8.0 & 10.1 & 9.0 & 8.0 \\
\hline
\end{tabular}

As the table shows, the biggest layer of temporally coloured language items is formed by the temporal meaning of succession (58.2\%); language manifestation of the rest of the meanings forms approximately equal layers (from $10.1 \%$ for frequency / oneness to $6.7 \%$ for priority). The temporal meaning of succession implies chronological arrangement of all the actions. It is observed in all the structural parts of narrative discourse: abstract, orientation, complicating action, result, evaluation and coda.

Succession becomes explicit by means of a certain variation on the Past Indefinite Tense, called The Past Narrative Tense, which expresses a number of semes:

a) reference of the action to the past;

b) oneness of the action;

c) localization of the action in time.

Here is a sentence to illustrate the use of the Past narrative Tense to express the outlined semes:

So I waited until I thought everyone had gone to bed, put on some clothes and went out into the fields near where I lived... with this Mars Bar... and buried it in a field, sort of destroying the evidence, you might say. 
As the provided example shows, throughout the narrative, the narrator uses verbs and participles associated with motion, the so-called verbs of physical action (waited, had gone, put on, went out, buried, destroying) to trace their actions, and also to correlate them with their emotional response to the narrated events.Apart from past tenses, present tenses sometimes occur in the narrative and not only for direct speech or asides. As Wolfson claims (1982), though narratives can be and often are told completely in the in past, the use of the present tense to refer to the past events is a feature of narrative, both oral and written, which occurs in many languages. This kind of Present Tense is called Historical. The use of a present tense in the context of a narrative must be seen as a way of placing the important events of the story in the same time orientation, as the telling, thus making the story more dramatic.

At the syntactic level the temporal meaning of succession is manifested by enumeration patterns made by simple extended and compound clauses. These patterns have a number of verbs of physical action in the form of Past Indefinite, as well as adverbs and noun+preposition collocations used as adverbials of time (then, suddenly, immediately, finally, eventually, the next morning, two hours later, after that, all of a sudden). Moreover, subordinate clauses of time with the conjunctions when, after are common. In narrative discourse the temporal meaning of priority is expressed by numeral+noun collocations with the adverb "ago" used as adverbials of time and subordinate clauses of time in which verbs of physical action are used in the Past Perfect tense. The retrospective function of The Past Perfect tense is seen in creating various associative bonds and overlapping various time layouts. Here are a few sentences to demonstrate it:

- $\quad$ And I discovered later that what had happened was that the parents of the boy, who'd died, had come early that morning and taken his body away to their village to bury him there.

- I was a bit - I was all right later on after I'd had a couple of brandies erm, but it only really came home to me what had happened at that point.

- Moreover, the adverbs "already, yet, just" frequently accompany the predicates in the Past perfect and intensify the meaning of priority, e.g.:

- $\quad$ And the Irish chap, who'd just wiped it out of his eyes and a little bit out of his hair, was suddenly completely covered again with a double layer.

- $\quad$ So I went into his room ... and ... he'd gone off already, he'd gone shopping, in fact.

At the lexical level, priority becomes explicit by the verbs remember, forget, recollect, originate, nouns memory, experience, the adjectives last, previous, that are characteristic of the meaning of temporal priority in their semantic structure, e.g.:

- I remember the bus turning over two or three times and of grabbing hold of a handle and eventually the bus came to rest upside down.

this guy...

This really originates from a friend. Mm... when I was a student of a university, and

- I think it's rather a unique experience, actually. I was in New York a few years ago and I wanted to read a particular poem, so I went along to the public library.

As for the correlation of the temporal meanings and the structural parts of narrative discourse, the meaning of priority is primarily observed in orientation, as can be seen in the last two of the given above examples.

The main syntactic device used in narrative discourse to express simultaneity is subordinate clauses of time with conjunctions "when, as", in which actions both of the main and subordinate clauses occupy one and the same point on time axis. Thus, both of them usually have predicates used in the same grammar tense, e.g.:

- $\quad Y o u$ know, you remember when I first went to Italy, I had some terrible bad luck.

- $\quad$ Anyway, while the two were getting the money, the one at the door started swearing at them, telling them to hurry up, to get a move on.

To express simultaneity, nouns denoting time segments, such as point, moment, point, are used along with the words that, particular, the same forming adverbials of time, e.g.:

- $\quad$ At the same moment the guard, I mean the bank guard, and that chap outside who has a machine gun, came flying through the door and lay face down on the floor and following him through the door were three masked men, which was absolutely terrifying.

- $\quad$ So at this particular point they were stopped and the coffin was opened and they were all arrested. 

point I panicked.

The temporal meaning of duration is manifested by the Past Continuous tense, the adverbs of duration "briefly, long, slowly, rapidly, gradually, constantly, lately, recently" and collocations like "all night, months and months, all the time, for a long time, by the third day, in those days, from that moment", used as adverbials of time or manner, as the following examples demonstrate:

- $\quad$ And... I was just going to come on leave to England, you see, and, obviously, it was... it was quite a long leave, you know, I was coming for three months, I think, it was.

- $\quad$ So we started operating the system, and it was a sort of, you know, we won a bit, we lost a bit, it went on for a long time.

- Well, I worked there for a couple of years more, and when I was finally leaving after two years, I was throwing out lots and lots of things: like magazines, books and so on.

Besides, the verbs "last, continue, wait", verb patterns "keep doing", "go on doing", nouns "time, period, stay" and adjectives "long, slow", participles "lasting, extended" are used. The idea of negative duration is highlighted by the adjectives with negative connotation like "tedious, tiring, tiresome, tired, exhausting, weary". The following narrative sentence exemplifies the use of the verb patterns "keep doing", the adjective "tired", as well as the adverbial "on my fourth day": on my fourth day.

I was getting a bit tired by this time and kept telling the family "I wouldn't really go skiing"

Moving on to the next temporal meaning, it should be mentioned first that Genette differentiates among singulative narrative (narrating once what happened once), repeating narrative (recounting more than once what happened once), and iterative narrative (relating one time what happened several times). At this point, we are interested in singulative actions, i.e. one-off actions reported by storytellers, seen in contrast to repeated events, viewed as typical, routine for the storyteller. In this sense, we differentiate temporal meanings of frequency and oneness presented in narrative discourse. The temporal meaning of frequency is manifested by the morphological tense Past Indefinite, while the temporal meaning of oneness is manifested by Present Indefinite. Apart from the Past Indefinite tense, the temporal meaning of frequency can be expressed by the Present Indefinite Perspective, the Future Indefinite, or the Present Continuous tenses. These forms foreground the idea of repeatedness, they highlight the idea that some action was customary for the narrator, as it is in the following example:

And you start off and you have to be able to bump up over the end of the plank and then you hurry along this very narrow plank over about fifty foot drop into er... muddy water. And it sags towards, as you get to the middle, and then when you start coming off or towards the other end it flips.

As the actions expressed by the Present Indefinite are not localized in time, are repeated, have generalizing meaning, nor do they move the action forward, they are neutral in terms of temporality. They qualify the actions of the narrator and other participants of the story and gain emotional character.

Frequency becomes explicit by the adverbs of frequency "always, never, ever, sometimes, again" and noun collocations with the pronoun "every, that, those" (every week, in those days, at that time), used as adverbials of time. Oneness becomes explicit by the adverb of frequency "once" and noun collocations with the pronoun "that" (on that day), or the adjective "particular" (on that particular morning), or the ordinal numerals (on the third day), used as adverbials of time. For oneness, the verb patterns "used to, to be used to" are used, while frequency is framed with the adjectives "only, unusual, unique". Time localization gets manifested by noun+preposition collocations with the prepositions "at, on, in" that identify a particular moment of time (at 10 o'clock, at the weekend, at Christmas, on Monday, in March of 2001), noun collocations "on the way (somewhere)", impersonal sentences denoting the time of action (It was about midnight), and the adverbs of time "now, then". Throughout narrative discourse, time localization is more customary for such structural parts, as orientation and complicating action. In the latter time localization marks the beginning of a new action or event. To illustrate, in the following episode from narrative discourse the adverbial group in June of last year is used in the orientation (which presents the time and place of the story) and the adverbial group on the Sunday belongs to the complicating action and opens a sequence of events:

Where were you going?

Well, I wasn't going anywhere. In fact, it was my husband, who works for a computer company and he was going on a business trip to Brussels. That was in June of last year. And... on the 
Sunday he went to the airport, in fact, I drove him with my small daughter, who was eighteen months old.

The observation upon lexical and grammar means realizing time concept has proved that in some cases one and the same language unit can express a number of temporal connotations, e.g. the verb pattern "keep doing" manifests both the seme of frequency and the seme of duration, while the adverb "then" can express both priority and succession:

- $\quad$ Then the telephone rang again and I picked up the receiver and it was my husband's father (succession).

- $\quad$ And we were given a nice lunch and then taken up to the shop, and I rearranged for the lessons and I started the beginners' class (succession).

- $\quad$ There weren't any casinos in England then (priority).

- $\quad$ And she told me what I thought then was rather an appalling story (priority).

In the first two of the given above narrative sentences the adverb then expresses the temporal meaning of succession, while in the third and fourth sentences it expresses priority.

\section{Discussion and conclusion}

The present study has been focused on the language representation of the time concept in English oral narrative discourse. A definition of narrative discourse has been offered. It has been proved that narrative production involves language manifestation of the concept of time seen as narrative's invariant characteristic feature. The result of the analysis is a detailed description of how exactly a temporal meaning is signalled at each language level in oral narrative discourse. The study revealed a number of words that have temporal seme in the structure of their lexical meaning, such as the verbs of action semantics. The carried out exploration of the syntactic level has shown that temporality is manifested by adverbial groups of time and manner, patterns with homogeneous predicates (expressed by verbs of action semantics), chain succession of compound and complex sentences. Moreover, a classification of temporal meanings characteristic of narrative discourse has been offered. The classification includes the following temporal meanings: succession, priority, simultaneity, frequency / oneness, duration and time localization. The analysis of the proportion of the defined temporal meanings in investigated narrative discourses has been carried out as well, proving that the biggest layer of temporally coloured language items is formed by the temporal meaning of succession, while the rest of the meanings form approximately equal layers. The main part of the study presents and analyses language manifestation of each of the singled out temporal meanings in oral narrative discourse.Another important finding is the identification of language units that can express a few temporal connotations and thus are included into the language bulks representing different temporal meanings. It is hoped that these studies will prove a complex cognitive nature of a linguistic signal. Uncovering language means of temporality in oral narrative discourse enabled disclosing its semiotic potential.

\section{REFERENCES}

Арутюнова, Н.Д. (1988)

Булыгина, Т.В., Шмелев, А.Д. (1997)

Гиль, О.Г. (2000)

Демьянков, В.3. (2005)

Колегаєва, I.М. (2018)
Типы языковых значений: Оценка. Событие. Факт. Москва: Наука. Arutjunova, N.D. (Arutyunova N.D. Tipy yazykovykh znachenij: Otsenka. Sobytiye. Fakt. Moskva: Nauka, 341 s.)

Языковая концептуализация мира (на материале русской грамматики). Москва: ЯРК. (Bulygina T.V., Shmelev A.D. Yazykovaya kontseptualizatsyya mira (na materiale russkoj grammatiki). Moskva: YaRK, $321 \mathrm{s.}$ )

Речевые проявления личности в устном рассказе нарративного типа: Дис. ...канд. филол. наук:. Москва, 2000. 271 с. (Gil, O.G. Rechevyie proyavleniya lichnosti v ustnom rasskaze narrativnogo tipa: Dis. ...kand. filol. nauk:. Moskva, 2000. 271 s.)

Текст и дискурс как термины и как слова обыденного языка. // Язык. Личность. Текст, Москва: Языки славянских культур, с. 34 - 55. (Demyankov, V.Z. Tekst i diskurs kak terminy i kak slova obydennogo yazyka. // Yazyk. Lichnost'. Tekst, Moskva: Yazyki slavyanskikh kul'tur, s. $34-55$.)

Конструювання номінативного поля концепту: етапи та одиниці. // Записки 3 романо-германської філології. 1 (40). Одеса: Астропринт, с. 121 - 127. (Kolehaieva, I.M. Konstruiuvannia nominatyvnoho polia kontseptu: etapy ta odynytsi. // Zapysky z romano-hermanskoi filolohii. 1 (40). Odesa: Astroprynt, s. $121-127$. 
Кубрякова, Е.С. (2005)

Степанов, Ю.С. (1991)

Фрумкина, Р.М. (1991)

Bamberg, M. (2008)

Biber, D. (1992)

Callaway, C. B., Lester, J. C. Narrative prose generation. // Artificial Intelligence, volume 139, issue 2, p. $213-$ (2002)

Carreiras, M. (2010)

David, D., Miclea, M., Opre, A. (2004)

Evans, V., Green, M. (2006)

Fauconnier, G. (2004)

Genette, G. (1980)

Herman, D. (2011)

Jahn, M. (2005)

Johnson, M. (2014)

Labov,W. (1972)

Lakoff, G. (1982)

Langacker, R. W. (1987)

Longacre, R.E. (1974)

Malouf, D. (2003)

Medin, D.L., Smith, E.E. (1984)

Polanyi, L. (2008)

Robinson, J. A. (1981)

Schiffrin, D. (1981)

Talmy, L. (2000)

Tillman, K. A. (2017)

Trask, R.L. (1999)

Wierzbicka, A. (2006)

Wolfson, N. (1982)

О термине "дискурс" и стоящей за ним структуре знания. // Язык. Личность. Tекст. Москва: Языки славянских культур, с. 23 - 33. (Kubryakova E.S. О termine "diskurs" i stoyaschej za nim strukture znaniya. // Yazyk. Lichnost'. Tekst. Moskva: Yazyki slavyanskikh kul'tur, s. 23-33.)

Концепт «причина» и два подхода к концептуальному анализу языка // Логический анализ языка. Культурные концептыл. Москва: Наука, с. $141-167$. (Stepanov, Yu.S. Kontsept «prichina» i dva podhoda k kontseptualnomu analizu yazyika // Logicheskiy analiz yazyika. Kulturnyie kontseptyi. Moskva: Nauka, s. 141 -167$.

Семантика и категоризация. Москва: Наука, 138 с. (Frumkina R.M. Semantika i kategorizatsiya. Moskva: Nauka, 138 s.)

Narrative Discourse and Identities. // Narratology beyond literary criticism, p. 213238

The Multi-Dimensional Approach to Linguistic Analyses of Genre Variation: An Overview of Methodology and Findings. // Computers and the Humanities, 26(5/6), p. 331-345.

252.

Language across the mind and brain. // Front. Psychology, 1:14 https://www.ncbi.nlm.nih.gov/pmc/articles/PMC3095382/ (7.05.2021)

The information-processing approach to the human mind: Basics and beyond. // Clinical Psychology, 60(4), pp.353-68.

Cognitive Linguistics: an Introduction. Edinburgh: Edinburgh University Press, 856 p.

Pragmatics and Cognitive Linguistics. In L. R. Horn and G. Ward (eds.). Handbook of Pragmatics, Malden, MA: Blackwell, p. 657-674.

Narrative Discourse: An Essay in Method, trans. Jane Lewin, Ithaca: Cornell University Press. p. 161-211.

The Emergence of Mind: Representations of Consciousness in Narrative Discourse in English. Lincoln: University of Nebraska Press, p. 1-40.

Cognitive Narratology. // Routledge Encyclopedia of Narrative Theory, London: Routledge, p. 67-71.

Morality for Humans: Ethical Understanding from the Perspective of Cognitive Science. Chicago: University of Chicago Press, $261 \mathrm{p}$.

The Transformation of Experience in Narrative Syntax. // Language in the Inner City, Philadelphia: Univ. of Pennsylvania Press, p. 354-96.

Categories and Cognitive Models. // Cognitive Science Program. Institute of Cognitive Studies, University of California at Berkeley, 1982. 103 p.

Foundations of Cognitive Grammar, Vol. 1: Theoretical Prerequisites. Stanford: Stanford Univ. Press, $540 \mathrm{p}$.

Narrative versus other discourse genre. In Brend, M. Advances in tagmetics. Columbia: University of Missouri, p. 357-376.

Made in England: Australia's British inheritance. Quarterly Essay, 12:1, 66 p.

Concepts and concept formation // Annual review of psychology, \#35. Cambridge, p. 113-138.

Telling the American Story. A Structural and Cultural Analysis of Conversational Storytelling Cambridge, MA: MIT Press, 215 p.

Personal narratives reconsidered. // Journal of American folklore, Vol. 94, № 371, p. $58-85$.

Tense Variation in Narrative. // Language, 57, p. 45-62.

Toward a Cognitive Semantics, vols. 1 and 2. Cambridge, MA: MIT Press, 573 p. Constructing the Concept of Time: Roles of Perception, Language, and Culture: dissertation for the degree PhD. San Diego: University of California, $198 \mathrm{p}$.

Key concepts in language and linguistics. London; New York: Routlege, 378 p. English: Meaning and culture. New York: Oxford University Press. 363 p.

The Conversational Historical Present in American English Narrative. Dordrecht: Foris, $126 \mathrm{p}$. 